\title{
Tetrandrine and thapsigargin release arachidonic acid from cells in culture and stimulate prostacyclin production in rat liver cells, but may do so by different pathways
}

\author{
Lawrence Levine*
}

Address: Department of Biochemistry, Brandeis University, Waltham, MA 02454, USA

Email: Lawrence Levine* - llevine@brandeis.edu

* Corresponding author

Published: 24 June 2005

BMC Pharmacology 2005, 5:12 doi:10.1186/1471-2210-5-12

This article is available from: http://www.biomedcentral.com/I47I-2210/5/I2

(c) 2005 Levine; licensee BioMed Central Ltd.

This is an Open Access article distributed under the terms of the Creative Commons Attribution License (http://creativecommons.org/licenses/by/2.0), which permits unrestricted use, distribution, and reproduction in any medium, provided the original work is properly cited.
Received: 26 January 2005

Accepted: 24 June 2005

\begin{abstract}
Background: Tetrandrine inhibits tumor cell proliferation and demonstrates chemoprevention in cancer models. Speculation on the association between its effects on $\mathrm{K}^{+}$and $\mathrm{Ca}^{2+}$ channels and cancer chemoprevention has been made. Thapsigargin also affects $\mathrm{K}^{+}$and $\mathrm{Ca}^{2+}$ conductance. Thapsigargin, however, is a weak tumor promoter in the two-stage model of mouse skin carcinogenesis, yet it can induce apoptosis in androgen-independent prostatic cancer cells. I have postulated that arachidonic acid release from cells in culture is associated with cancer chemoprevention. The effects of tetrandrine and thapsigargin on arachidonic acid release from human colon carcinoma and rat liver cells and prostacyclin production by rat liver cells are compared in the current studies.
\end{abstract}

Results: Tetrandrine and thapsigargin stimulate arachidonic acid release from human colon carcinoma and rat liver cells and prostacyclin production in rat liver cells. The stimulation by tetrandrine is not affected by incubation with actinomycin $\mathrm{D}, 100 \mathrm{mM} \mathrm{KCl}$, the $\left[\mathrm{Ca}^{2+}\right]_{\mathrm{i}}$ chelator, I,2bis (o-amino-5-fluorophenoxy) ethane- $N, N, N^{\prime}, N^{\prime}$, -tetraacetic acid tetraacetoxymethylester (BAPTA/AM) or in the absence of extracellular $\mathrm{Ca}^{2+}$. In contrast, stimulation by thapsigargin is inhibited by incubation with actinomycin $D, 100 \mathrm{mM} \mathrm{KCl}$, BAPTA/AM or in the absence of extracellular $\mathrm{Ca}^{2+}$.

Conclusion: Both tetrandrine and thapsigargin stimulate arachidonic acid release, but based on the different results obtained in the presence of actinomycin $D$, the $\left[\mathrm{Ca}^{2+}\right]_{i}$ chelator, $100 \mathrm{mM} \mathrm{KCl}$ and in the absence of extracellular $\mathrm{Ca}^{2+}$, the mechanisms leading to this release and pathways leading to apoptosis and/or cancer chemoprevention may be different. Stimulations by tetrandrine may be mediated by activation of a secretory phospholipase $A_{2}$, whereas thapsigargin's stimulations may be mediated by the cytoplasmic $\mathrm{Ca}^{2+}$-dependent phospholipase $\mathrm{A}_{2}$.

\section{Background}

Tetrandrine (TET), a bisbenzylisoquinoline (Fig. 1a), isolated from the root of the plant Stephania tetrandra has a number of potential medicinal properties. These include blockage of voltage-gated $\mathrm{Ca}^{2+}$ channels [1], large-conductance $\mathrm{Ca}^{2+}$ activated $\mathrm{K}^{+}(\mathrm{BK})$ channels, and intracellular $\mathrm{Ca}^{2+}$ pumps [1-6]. TET also has anti-inflammatory $[2,7]$ and anti-cancer activities [8,9]. TET stimulates 
prostaglandin ( $\mathrm{PG}) \mathrm{E}_{2}$ production by macrophages [10], probably after first releasing the substrate, arachidonic acid (AA) by altering phospholipase (Plase) activities. TET also induces apoptosis in many cell types including human leukemic (U937), human lung carcinoma (A549), human hepatoblastoma (HEPG2), neuro 2a mouse neuroblastoma and rat glioma cells (C-6) [11-14].

Thapsigargin (THAP), a hexaoxygenated tetracycle sesquiterpine lactone, (Fig. 1b) isolated from the plant Thapsia garganica, also has a number of potential medicinal applications [15]. However, THAP is classified as a weak tumor promoter as measured in the two-stage model of mouse skin carcinogenesis [16]. Nevertheless, THAP [17] and its enzymatically modified analog [18] have been proposed as targeted therapy for prostate cancer. THAP, like TET, blocks intracellular calcium pumps resulting in increased cytoplasmic $\mathrm{Ca}^{2+},\left(\left[\mathrm{Ca}^{2+}\right]_{\mathrm{i}}\right)$ [reviewed in 15]. It also affects ion channels. THAP induces a $\mathrm{Ca}^{2+}$-dependent release of AA from $\left[{ }^{3} \mathrm{H}\right]$-AA labelled macrophages and stimulates AA metabolism in the rat peritoneal macrophages [19]. THAP induces apoptosis in many cells including human neuroblastoma, colon cancer and prostate cancer cells and thymocytes [17,20-22].

Based on the stimulation of AA release by known cancer chemopreventative agents, I have proposed that AA release by cells is associated with cancer chemoprevention [23-27], possibly, but not necessarily, by activating a secreted tumor suppressor phospholipase $A_{2}\left(P_{L A}\right)$ $[28,29]$. In this report, evidence is presented that TET, a potential cancer chemopreventive compound, and THAP, a weak tumor promoter that also possesses potential cancer preventative properties for androgen-independent prostate cancer, both stimulate AA release from human colon carcinoma and rat liver cells. Both compounds also stimulate prostacyclin $\left(\mathrm{PGI}_{2}\right)$ production in rat liver cells. The release of AA and AA metabolites appears to be initiated by different mechanisms.

\section{Results}

TET and THAP release AA from human colon carcinoma (HT-29) cells and rat liver (C-9) cells in a concentrationdependent fashion (Fig. 2a - 2d respectively). As little as 0.1 to $0.3 \mu \mathrm{M}$ THAP stimulates AA release. With both HT29 and C-9 cells, THAP is about 10 to 30 times more potent than TET. Characterizations of these effects are shown in Table 1. Pre-incubation with actinomycin D partially inhibits stimulation by THAP but does not affect stimulation by TET. TET's stimulation of AA release does not require new mRNA synthesis, whereas THAP's stimulation does. As shown below, THAP's stimulation is mediated, in part, by the $\mathrm{Ca}^{2+}$-dependent $\mathrm{PLA}_{2}$ an induced enzyme. The absence of extracellular $\mathrm{Ca}^{2+}$ partially inhibits THAP's stimulations but does not affect the AA release

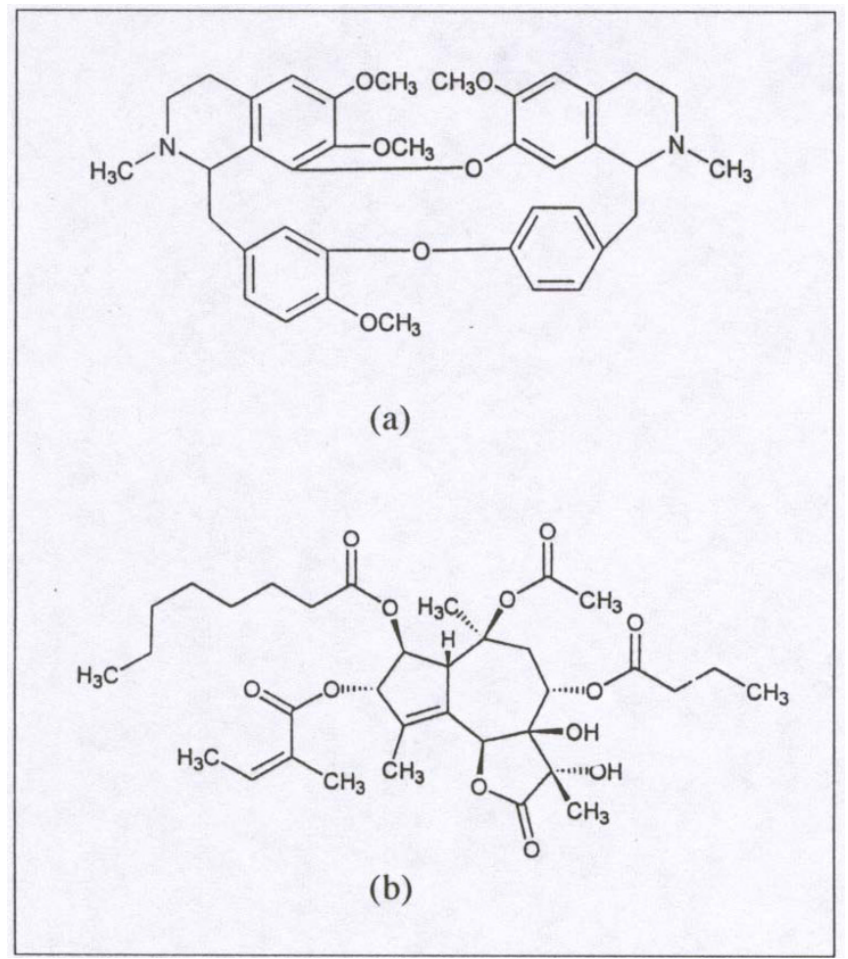

Figure I

a): Tetrandrine (TET), isolated from the plant Stephania tetrandra (Structure reproduced with permission from $G$. Wang [9]) and b): Thapsigargin(THAP), isolated from the plant Thapsia garganica (Structure reproduced with permission from S. B. Christensen [I5]).

stimulated by TET. Depolarization of the cells with 100 $\mathrm{mM} \mathrm{KCl}$ does not affect TET's stimulations, but does partially inhibit release of AA stimulated by THAP. Pre-incubation with the L-TYPE $\mathrm{Ca}^{2+}$ channel blocker, diltiazem, has no effect on the actions of either TET or THAP in HT29 or C-9 cells.

The role of $\left[\mathrm{Ca}^{2+}\right]_{\mathrm{i}}$ in these stimulations is striking. While pre-incubation with the $\left[\mathrm{Ca}^{2+}\right]_{\mathrm{i}}$ chelator, BAPTA/AM (16 $\mu \mathrm{g} / \mathrm{ml}$ ), does not affect TET's stimulation of AA release from HT-29 cells, such treatment does inhibit THAP's stimulation of AA release from the HT-29 cells (Fig. 3, Table 1). Thus, a role for intracellular $\mathrm{Ca}^{2+}$ pumps is strongly suggested only for the action of THAP. Ohuchi $e t$ al $[19]$ had shown that $\left[\mathrm{Ca}^{2+}\right]_{\mathrm{i}}$ increased within 2 min after treatment with THAP as measured by fluorescence changes in Quin 2 loaded peritoneal cells. A similar rise in $\left[\mathrm{Ca}^{2+}\right]_{\mathrm{i}}$ has been measured after administration of THAP to thymocytes, rat liver microsomes [30] and in macrophages, astrocytoma cells, fibroblasts and human tumor lymphocytes [31]. The findings that the increased AA release is stimulated 5 minutes after incubation of HT-29 

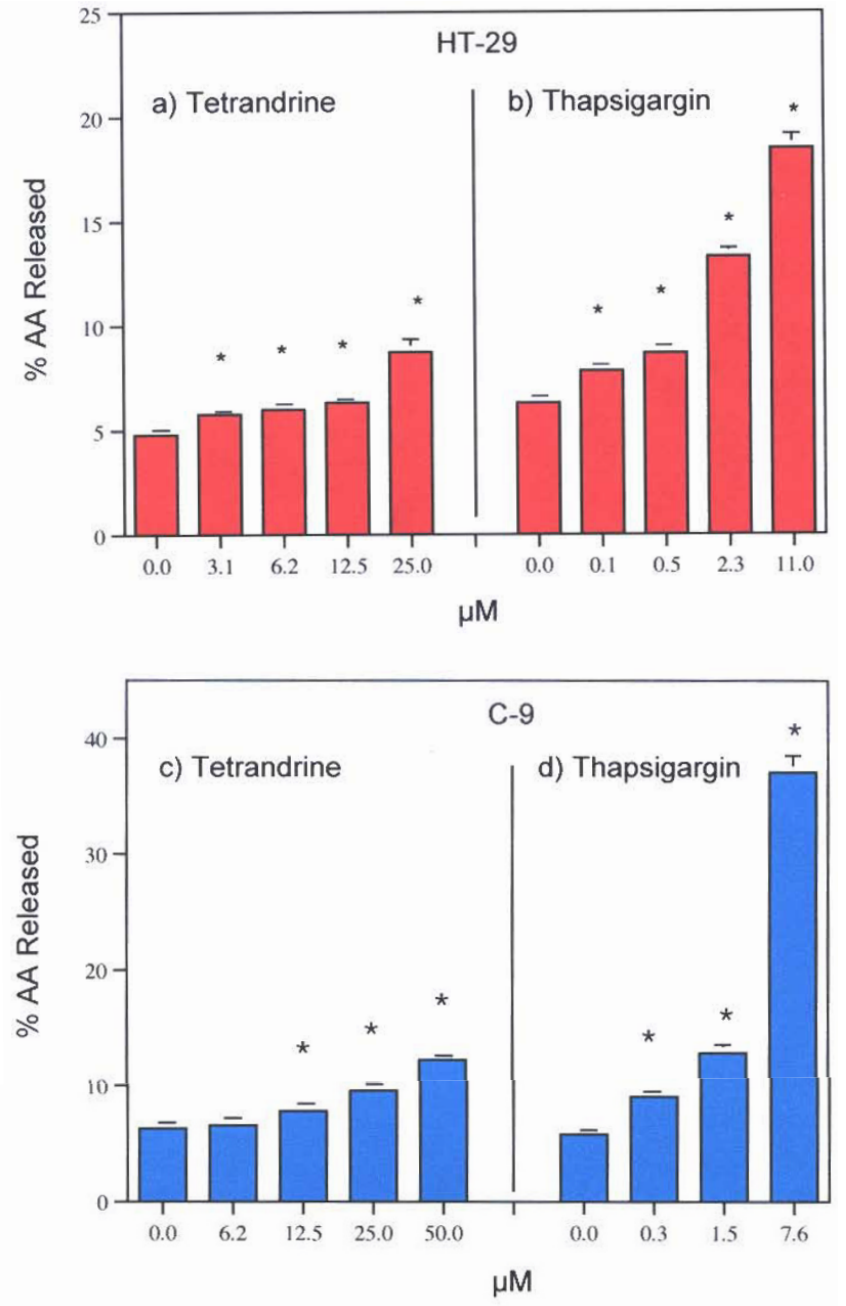

Figure 2

Effect of a) TET and b) THAP on AA release from HT-29 cells. Effect of c) TET and d) THAP on AA release from C-9 cells. The data are representative of several experiments. The analyses were performed with triplicate or quadruplicate dishes. * = Statistically significant vs MEM/BSA

and C-9 cells with THAP is consistent with a role for increased $\left[\mathrm{Ca}^{2+}\right]_{\mathrm{i}}$ in the activities of THAP (Fig $4 \mathrm{a}, 4 \mathrm{~b}$ ).

While both cells express COX activity [32,33], only the major product of COX activity $\left(\mathrm{PGI}_{2}\right)$ can be quantitatively estimated at the low cell densities used in these studies. Both TET and THAP stimulate $\mathrm{PGI}_{2}$ (measured as 6-keto PGF $_{1 \alpha}$ ) production in these C-9 cells (Fig. 5a, 5b). As with AA release, THAP is at least 10-times more potent at stimulating $\mathrm{PGI}_{2}$ production than TET.
The likely role of $\left[\mathrm{Ca}^{2+}\right]_{\mathrm{i}}$ in the stimulation of $\mathrm{PGI}_{2}$ production by THAP is shown in Fig. 6. Chelation of the increased $\left[\mathrm{Ca}^{2+}\right]_{i}$ with BAPTA/AM completely inhibits the stimulation by THAP but has no effect on the stimulation with TET.

\section{Discussion}

It has been proposed that the cancer chemopreventative properties attributed to TET reside in its ability to effect ion channels which leads to inhibition of cell proliferation and apoptosis [9]. Retinoic acids, tamoxifen, PPARagonists, (e.g GW-7845), some non-steroidal anti-inflammatory drugs, vitamin $\mathrm{D}_{3}$, anti-oxidants, (e.g resveratrol and caffeic acid phenylester) and statins all release AA from cells in culture [23-26]. All have been shown to have cancer preventative properties. Results of studies on correlation, if any, of AA release and cancer chemoprevention by TET or THAP have not been published. For the purpose of this study, however, I have postulated that the cancer chemopreventive properties of the test agent are causally related to the capacity of that ligand to release AA. I have also suggested that most, if not all, of these agents at $\mu \mathrm{M}$ concentrations, may be intercalating into the cell membrane and releasing AA as a result of activated PLAse activity $[25,26]$.

The mechanism of action of non-steroidal anti-inflammatory drugs that leads to apoptosis and cancer chemoprevention also involves stimulation of AA release and is associated with sphingomyelin to ceramide conversion [34]. The AA release probably results in ceramide-mediated apoptosis [35]. Both TET and THAP stimulate the release of AA from human colon carcinoma and rat liver cells. TET does prevent cancer [reviewed in 8] but THAP is considered to be a weak tumor promotor as measured in the two-stage model of mouse skin carcinogenesis [19]. THAP and some of its analogs, however, do induce apoptosis in androgen-independent prostatic cancer cells $[17,18,36]$. Apoptotic effects of THAP also have been reported in thymocytes and mouse lymphomas, including the WRH17-2 and WHB12 cell lines [17,20-22].

Clear differences in the pathways of AA release stimulated by TET and THAP were found in this study. TET stimulates AA release (Fig. 2) in HT-29 and C-9 cells and $\mathrm{PGI}_{2}$ production in C-9 cells (Fig. 5). It has been reported that TET blocks voltage-gated $\mathrm{Ca}^{2+}$ channels [1-7] and depolarizes the cells [8], but blockage of these channels does not affect AA release (Table 1). Nor is the AA release stimulated by TET blocked by pre-incubation of the cells with actinomycin $\mathrm{D}$, in the presence of $100 \mathrm{mM} \mathrm{KCl}$ or in the absence of extracellular $\mathrm{Ca}^{2+}$. It is interesting to note that cycloheximide $(178 \mu \mathrm{M})$, did not affect TET's induced apoptosis in human lymphoblasts (CEM-C7) [37]. TET's stimulation of AA release is not affected by the $\left[\mathrm{Ca}^{2+}\right]$ 
Table I: Effects of Diltiazem $(50 \mu \mathrm{g} / \mathrm{ml})$, Actinomycin D $(\mathrm{l} \mu \mathrm{g} / \mathrm{ml})$, EGTA $(\mathrm{I} \mathrm{mM}), \mathrm{KCl}(100 \mathrm{mM})$, and BABTA/AM (I6 $\mu \mathrm{g} / \mathrm{ml})$ on AA Release from HT-29 or C-9 Cells stimulated by TET or THAP.

\begin{tabular}{|c|c|c|c|c|}
\hline \multirow[t]{2}{*}{ Some biological effects* } & \multirow[t]{2}{*}{ Agent tested } & \multirow[t]{2}{*}{ Action of test agent } & \multicolumn{2}{|c|}{ AA Release } \\
\hline & & & HT-29 & C-9 \\
\hline TET & Diltiazem & $\begin{array}{l}\text { Blocks L-type } \mathrm{Ca}^{2+} \\
\text { channels }\end{array}$ & $\mathrm{NI}$ & $\mathrm{NI}$ \\
\hline Ion Channels & Actinomycin D & Inhibits RNA synthesis & $\mathrm{NI}$ & $\mathrm{NI}$ \\
\hline Apoptosis & EGTA & Chelates extracellular $\mathrm{Ca}^{2+}$ & $\mathrm{NI}$ & $\mathrm{NI}$ \\
\hline Depolarization & $100 \mathrm{mM} \mathrm{KCl}$ & Depolarizes & $\mathrm{NI}$ & $\mathrm{NI}$ \\
\hline$\left[\mathrm{Ca}^{2+}\right]_{1}$ & BAPTA/AM & Chelates $\left[\mathrm{Ca}^{2+}\right]_{\mathrm{i}}$ & $\mathrm{NI}$ & $* *$ \\
\hline THAP & Diltiazem & $\begin{array}{l}\text { Blocks L-type } \mathrm{Ca}^{2+} \\
\text { channels }\end{array}$ & $\mathrm{NI}$ & $\mathrm{NI}$ \\
\hline Ion Channels & Actinomycin D & Inhibits RNA synthesis & $\downarrow$ & $\downarrow$ \\
\hline Apoptosis & EGTA & Chelates extracellular $\mathrm{Ca}^{2+}$ & $\downarrow$ & $\downarrow$ \\
\hline Depolarization & $100 \mathrm{mM} \mathrm{KCl}$ & Depolarizes & $\downarrow$ & $\downarrow$ \\
\hline$\left[\mathrm{Ca}^{2+}\right]_{\mathrm{i}}$ & BAPTA/AM & Chelates $\left[\mathrm{Ca}^{2+}\right]_{l}$ & $\downarrow$ & $* *$ \\
\hline
\end{tabular}

\footnotetext{
$*=$ References in text

$\mathrm{NI}=$ No Inhibition (or stimulation)

$\downarrow=$ Inhibition: statistically significant

$* *=$ BAPTA $/$ AM $(16 \mu \mathrm{g} / \mathrm{ml})$ stimulates AA release $(6.17 \pm 0.088(4))$, MEM/BSA control vs (II.6 $\pm 0.322(4))$, BAPTA/AM (I6 $\mu \mathrm{g} / \mathrm{ml})$. Thus, the

effect of BAPTA/AM on C-9 cells is not recorded.
}

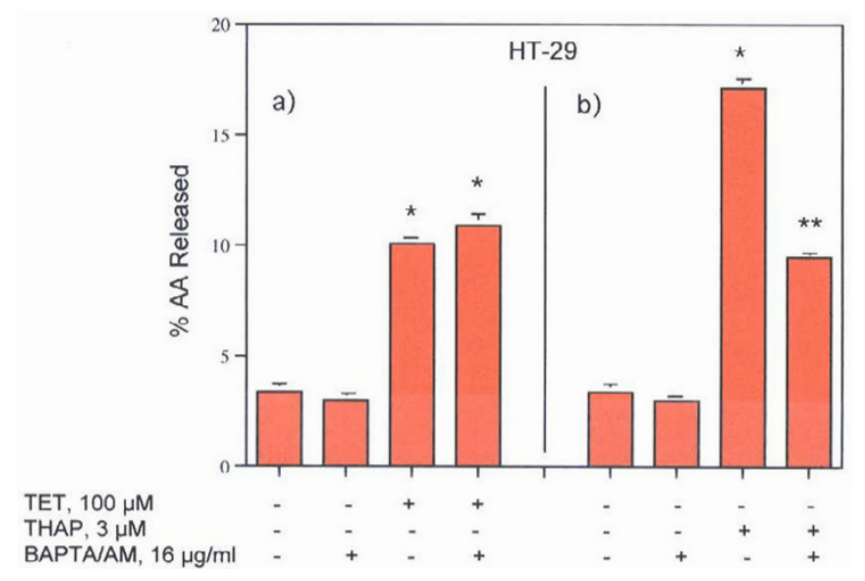

Figure 3

Effect of BAPTA/AM, $16 \mu \mathrm{g} / \mathrm{ml}$, on AA release by a) TET and b) THAP from HT-29 cells. The data are representative of two experiments, each with similar results. The analyses were performed on quadruplicate dishes. $*$ = Statistically significant vs MEM/BSA.

chelator, BAPTA/AM (Fig. 3). In contrast, THAP's release of AA by HT-29 cells is blocked by BAPTA/AM (Fig. 3), is inhibited by pre-incubation with actinomycin D, is inhibited by EGTA and is inhibited when the cells are incubated in $100 \mathrm{~m} \mathrm{M} \mathrm{KCl}$ (Table 1 ). That the rise in $\left[\mathrm{Ca}^{2+}\right]_{\mathrm{i}}$ resulting from treatment with THAP appears to be associated with the stimulation of AA release is suggested by the relatively early increase, after 5 minutes, of AA release (Fig. 4). Both TET and THAP stimulate $\mathrm{PGI}_{2}$ production in the C-9 cells (Fig. 5), but only the $\mathrm{PGI}_{2}$ production stimulated by THAP is inhibited by BAPTA/AM (Fig 6).

The relationship between AA release and cancer chemoprevention by TET and THAP could be explained, in part, by implicating the $\mathrm{PLA}_{2}$ enzymes that catalyze the release of AA from phospholipids. The tumor suppressing sPLA may be only one of sixteen structurally different $\mathrm{PLA}_{2}$ enzymes [38,39]. If the tumor suppressor genes are overexpressed or activated, at least two cancer preventative pathways may result, one from the activity of the group $11 \mathrm{~A}$ tumor suppressor [Reviewed in [39]] and a second from the AA released. The proximity of the PLA 2 to the AAesterified phospholipid after treatment of the cells is of importance, and may depend on the location of binding of the test agent. For example, celecoxib binds at the upper hydrocarbon core, close to the phospholipid head groups whereas rofeco

xib binds at the polar head groups of the membrane [40]. Celecoxib and rofecoxib differ in their release of AA [41]. TET may activate a tumor suppressing $\mathrm{SPLA}_{2}$, while THAP induces the $\mathrm{Ca}^{2+}$-dependent $\mathrm{CPLA}_{2}$. Both would lead to AA release.

\section{Conclusion}

Cells treated with tetrandrine and thapsigargin share several common features including pathways that lead to 

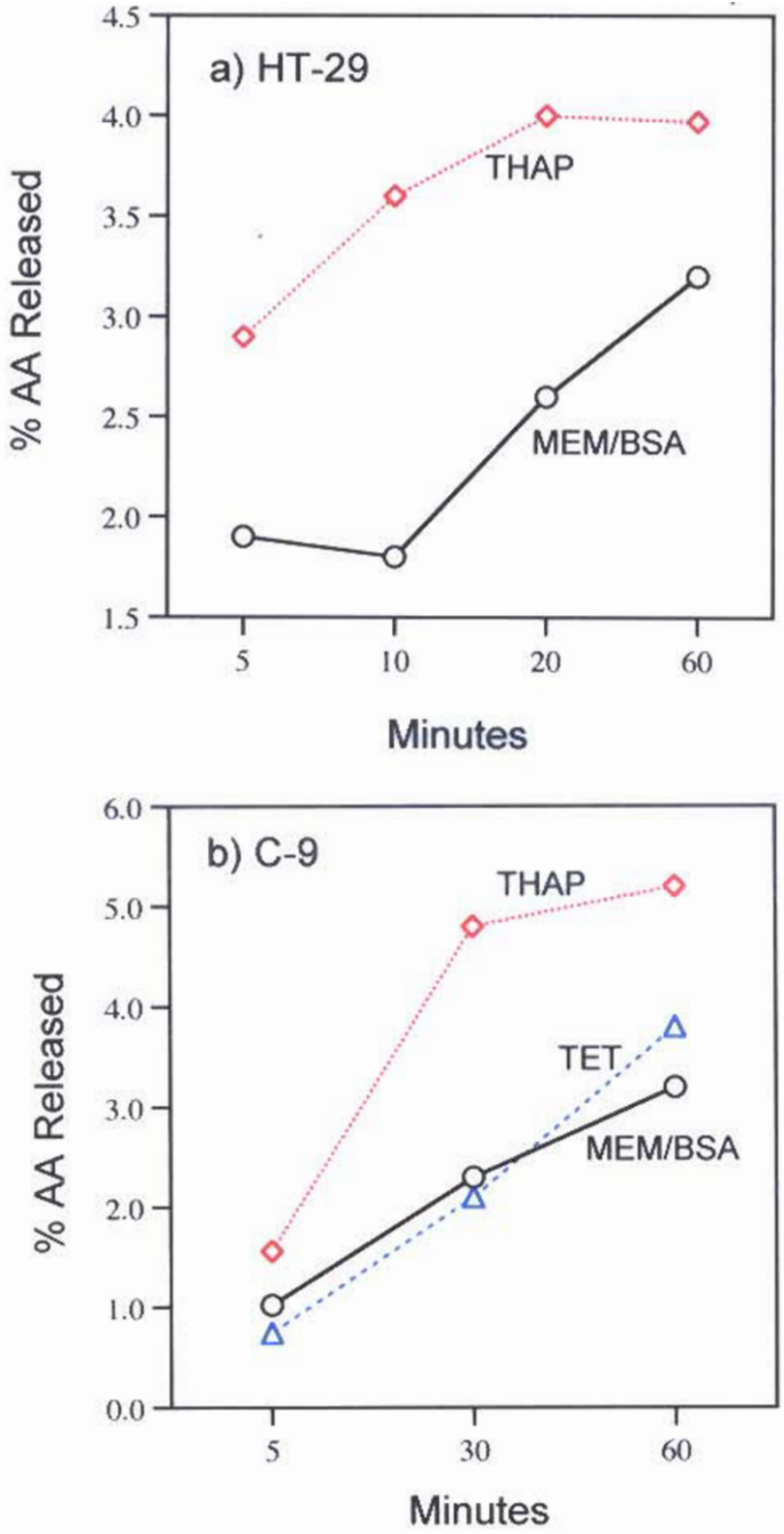

Figure 4

Time-course of AA release from a) HT-29 and b) C-9 cells by TET $(50 \mu \mathrm{M})$ and THAP $(2 \mu \mathrm{M})$. The analyses were performed on duplicate dishes. After the 60 minutes incubation, the AA release by TET is not statistically significant. TET's stimulation of AA release from HT-29 cells was not done.

induction of apoptosis. These properties probably reflect their interaction with cell membranes and the altered expression of signaling processes. One reaction that does not appear to be shared is deesterification of a phospholipid by a PLA 2 . Based on the effects of inhibition of $m$ RNA

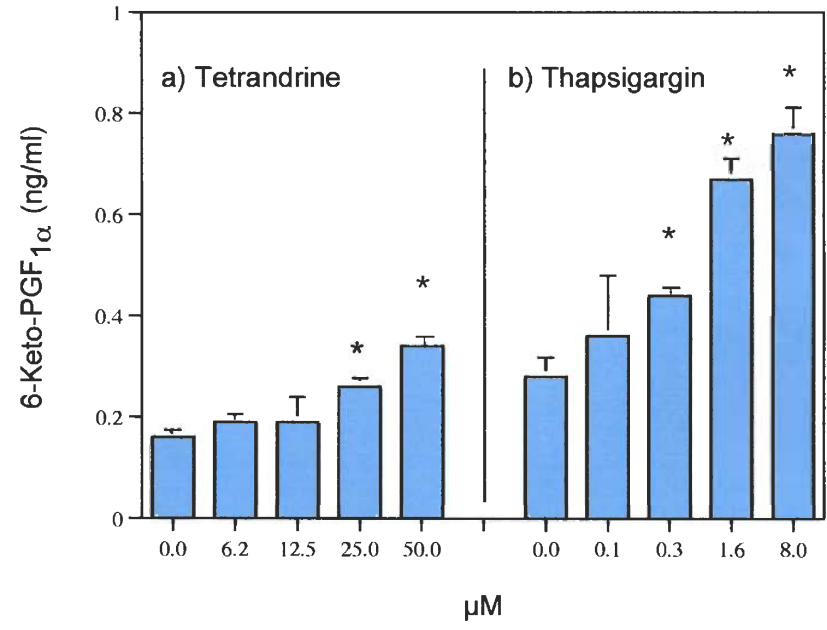

Figure 5

Effects of a) TET and b) THAP on PGI (6-keto-PGF $_{\mid \alpha}$ ) production in rat liver cells (C-9). The data are representative of several experiments. The analyses were performed with triplicate dishes. $*=$ Statistically significant vs MEM/BSA.

synthesis, $100 \mathrm{mM} \mathrm{KCl}$, extracellular and especially intracellular $\mathrm{Ca}{ }^{2+}$, thapsigargin's release is mediated, in part, by a $\mathrm{Ca}{ }^{2+}$-dependent $\mathrm{PLA}_{2}$, whereas tetrandrine's stimulated release is mediated by a secretory PLA $\mathrm{P}_{2}$. In addition to the altered signaling properties that accompany the membrane intercalation, both tetrandrine and thapsigargin release biologically active AA.

\section{Methods}

The rat liver (C-9 cell line) were purchased from the American Type Culture Collection (Manassas, VA, USA) and the human colon carcinoma (the HT-29 cell line) was obtained from Dr. Basil Rigas, Chief, Division of Cancer Prevention, SUNY at Stony Brook, NY, USA. They were maintained in Eagle's minimum essential medium (MEM) supplemented with $10 \%$ fetal bovine serum. $\left[{ }^{3} \mathrm{H}\right]$ AA $(91.8 \mathrm{Ci} / \mathrm{mmol})$ was obtained from NEN Life Science Products, Inc. (Boston, MA, USA). BAPTA/AM, the $\left[\mathrm{Ca}^{2+}\right]_{\mathrm{i}}$ chelator, diltiazem, the L-type $\mathrm{Ca}^{2+}$ channel agonist, tetrandrine and thapsigargin were purchased from BIOMOL International, (Plymouth, PA, USA). All other reagents were from Sigma Chemical Co. (St. Louis, MO, USA) or Calbiochem, (San Diego, CA, USA).

Two days prior to experiments, the HT-29 or C-9 cells were treated with $0.25 \%$ trypsin-EDTA and, after addition of minimal essential media (MEM) containing 10\% fetal calf serum, the floating cells were seeded on to $35 \mathrm{~mm}$ culture dishes. The plating densities varied from 0.1 to $0.5 \times$ $10^{5}$ cells $/ 35 \mathrm{~mm}$ dish. The freshly seeded cultures were 


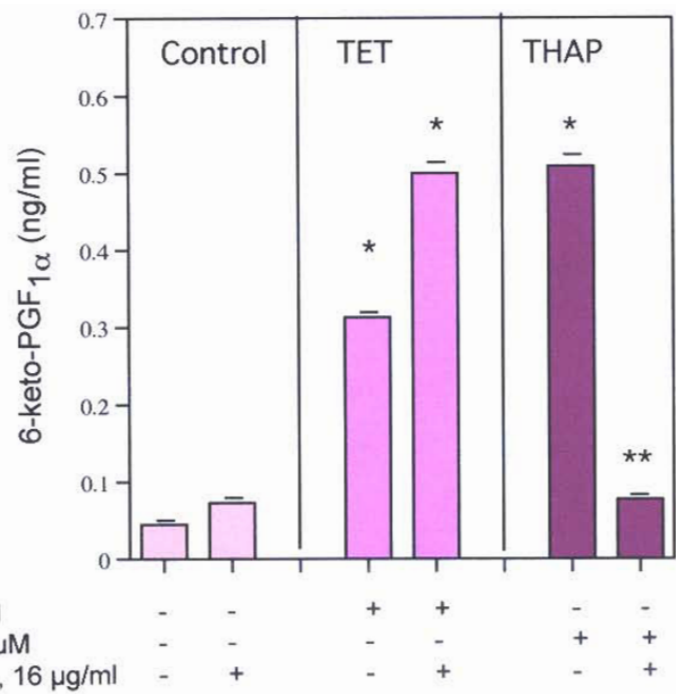

Figure 6

Effect of BAPTA/AM, $16 \mu \mathrm{g} / \mathrm{ml}$ on THAP's stimulated $\mathrm{PGI}_{2}$ production by rat liver cells. The data are representative of two experiments, each with similar results. $*=$ Statistically significant vs THAP or BAPTA/AM. ** = Statistically significant vs THAP.

incubated for 24-h to allow for cell attachment. After decantation of MEM containing the fetal bovine serum, $1.0 \mathrm{ml}$ fresh MEM containing 10\% fetal bovine serum and $\left[{ }^{3} \mathrm{H}\right] \mathrm{AA}(0.2 \mathrm{mCi} / \mathrm{ml})$ were added and the cells incubated for another 24-h. The cells were washed 4 times with MEM and incubated for various periods of time with $1.0 \mathrm{ml}$ of MEM containing $1.0 \mathrm{mg}$ BSA/ml (MEM/BSA) and different concentrations of each compound. The culture fluids were then decanted, centrifuged at $2000 \times \mathrm{g}$ for $10 \mathrm{~min}$, and $200 \mu \mathrm{l}$ of the supernate counted for radioactivity. The MEM/BSA values are the control values. Radioactivity recovered in the washes before the incubation was compared to input radioactivity to calculate the \% radioactivity incorporated into the cells. For experiments on the effects of actinomycin D, the HT-29 or C-9 cells were washed with MEM 4 times, incubated with actinomycin D (1 $\mu \mathrm{M})$ for 2 -h, washed once and incubated again for 6 -h in the presence or absence of actinomycin $\mathrm{D}(1 \mu \mathrm{M})$. For the effects of BAPTA/AM, the pre-incubation was 50 minutes. For $\mathrm{PGI}_{2}$ production, $1.0 \mathrm{ml}$ of MEM supplemented with $10 \%$ fetal bovine serum, void of $\left[{ }^{3} \mathrm{H}\right] \mathrm{AA}$, was added after the first 24-h incubation. The cells were incubated for another 24-h, washed three times with MEM, then incubated with the compounds in MEM/BSA for various periods of time. The culture fluids were decanted and analyzed for 6-keto-PGF ${ }_{1 \alpha^{\prime}}$ the stable hydrolytic product of $\mathrm{PGI}_{2}$, by radioimmunoassay [42].
The $\left[{ }^{3} \mathrm{H}\right]$ AA release is presented as a percentage of the radioactivity incorporated by the cells. Except for the timecourse experiments, which used duplicate dishes, three to five culture dishes were used for each experimental point. The data are expressed as mean values \pm SEM. The data were evaluated statistically by the unpaired Student's t-test. A $P$ value $<0.05$ was considered significant.

\section{Acknowledgements}

My thanks to Hilda B. Gjika for preparation of the manuscript and to Dr. Armen H. Tashjian, Jr., Department of Genetic and Complex Diseases, Harvard School of Public Health, for his continuing interest in these studies.

\section{References}

I. Wang G, Lemos JR: Tetrandrine: a new ligand to block voltagedependent $\mathrm{Ca}^{2+}$ and $\mathrm{Ca}^{+}$- activated $\mathrm{K}^{+}$channels. Life Sci 1995 , 56:295-306

2. Kwan CY, Achike FI: Tetrandrine and related bis-benzylisoquinoline alkaloids from medicinal herbs: cardiovascular effects and mechanisms of action. Acta Pharmacol Sin 2002, 23: 1057-1068.

3. Yao WX, liang $M X$ : Effects of tetrandrine on cardiovascular electrophysiologic properties. Acta Pharmacol Sin 2002, 23:1069-1074.

4. Hagiwara M, Adachi-Akahane S, Nagao T: High-affinity binding of $\left[{ }^{3} \mathrm{H}\right]$ DTZ323 to the diltiazem-binding site of L-type $\mathrm{Ca}^{2+}$ channels. Eur J Pharmacol 2003, 466:63-7I.

5. $\mathrm{Wu} \mathrm{SN}$ : Large-conductance $\mathbf{C a}^{2+}$ activated $\mathbf{K}^{+}$channels: physiological role and pharmacology. Curr Med Chem 2003, |0:649-66|.

6. Ransom CB, Liu X, Sontheimer H: BK channels in human glioma cells have enhanced calcium sensitivity. Glia 2002, 38:28I-29I.

7. Lai JH: Immunomodulatory effects and mechanisms of plant alkaloid tetrandrine in autoimmune diseases. Acta Pharmacol Sin 2002, 23:1093-1101.

8. Chen YJ: Potential role of tetrandrine in cancer therapy. Acta Pharmacol Sin 2002, 23: I 102-1 I06.

9. Wang G, Lemos JR, ladecola C: Herbal alkaloid tetrandrine: from an ion channel blocker to inhibitor of tumor proliferation. Trends Pharmacol Sci 2004, 25: I20-123.

10. Pang L, Hoult JR: Cytotoxicity to macrophages of tetrandrine, an antisilicosis alkaloid, accompanied by an overproduction of prostaglandins. Biochem Pharmacol 1997, 53:773-782.

II. Lai YL, Chen YJ, Wu TY, Wang SY, Chang KH, Chung CH, Chen ML: Induction of apoptosis in human leukemic U937 cells by tetrandrine. Anticancer Drugs 1998, 9:77-81.

12. Lee JH, Kang GH, Kim KC, Kim KM, Park DI, Choi BT, Kang HS, Lee YT, Choi YH: Tetrandrine-induced cell cycle arrest and apoptosis in A549 human lung carcinoma cells. Int J Oncol 2002, 2l: $1239-1244$.

13. Yoo SM, Oh SH, Lee SJ, Lee BW, Ko WG, Moon CK, Lee BH: Inhibition of proliferation and induction of apoptosis by tetrandrine in HepG2 cells. J Ethnopharmacol 2002, 81:225-229.

14. Jin Q, Kang C, Soh Y, Sohn NW, Lee J, Cho YH, Baik HH, Kang I: Tetrandrine cytotoxicity and its dual effect on oxidative stress-induced apoptosis through modulating cellular redox states in Neuro 2 a mouse neuroblastoma cells. Life Sci 2002, 71:2053-2066.

15. Treiman M, Caspersen C, Christensen SB: A tool coming of age: thapsigargin as an inhibitor of sarco-endoplasmic reticulum $\mathrm{Ca}^{2+}$-ATPases. Trends Pharmacol Sci 1998, 19:131-135.

16. Hakii H, Fujiki H, Suganuma M, Nakayasu M, Tahira T, Sugimura $T$, Scheuer PJ, Christensen SB: Thapsigargin, a histamine secretagogue, is a non-12-0-tetradecanoylphorbol-13-acetate (TPA) type tumor promoter in two-stage mouse skin carcinogenesis. J Cancer Res Clin Oncol 1986, I I I:I77-I8I.

17. Furuya $Y$, Lundmo $P$, Short $A D$, Gill DL, Isaacs JT: The role of calcium, $\mathrm{pH}$, and cell proliferation in the programmed (apoptotic) death of androgen-independent prostatic cancer cells induced by thapsigargin. Cancer Res 1994, 54:6167-6175.

18. Denmeade SR, Jakobsen CM, Janssen S, Khan SR, Garrett ES, Lilja H, Christensen SB, Isaacs JT: Prostate-specific antigen-activated 
thapsigargin prodrug as targeted therapy for prostate cancer. J Natl Cancer Inst 2003, 95:990- 1000.

19. Ohuchi K, Sugawara T, Watanabe M, Hirasawa N, Tsurufuji S, Fujiki $H$, Christensen SB, Sugimura T: Analysis of the stimulative effect of thapsigargin, a non-TPA-type tumour promoter, on arachidonic acid metabolism in rat peritoneal macrophages. $\mathrm{Br}$ J Pharmacol 1988, 94:917-923.

20. Jiang S, Chow SC, Nicotera P, Orrenius S: Intracellular $\mathbf{C a}^{2+}$ signals activate apoptosis in thymocytes: studies using the $\mathrm{Ca}^{2+}$ ATPase inhibitor thapsigargin. Exp Cell Res 1994, 21 2:84-92.

21. Kitamura Y, Miyamura A, Takata K, Inden M, Tsuchiya D, Nakamura $\mathrm{K}$, Taniguchi T: Possible involvement of both endoplasmic reticulum-and mitochondria-dependent pathways in thapsigargin-induced apoptosis in human neuroblastoma SH-SY5Y cells. J Pharmacol Sci 2003, 92:228-36.

22. He Q, Montalbano J, Corcoran C, Jin W, Huang Y, Sheikh MS: Effect of Bax deficiency on death receptor 5 and mitochondrial pathways during endoplasmic reticulum calcium pool depletion-induced apoptosis. Oncogene 2003, 22:2674-2679.

23. Levine L: Tamoxifen and the raloxifene analog LYII70I8: their effects on arachidonic acid release from cell in culture and on prostaglandin $I_{2}$ production by rat liver cells. BMC Cancer 2004.

24. Levine L: Does the release of arachidonic acid from cells play a role in cancer chemoprevention? FASEB J 2003, 17:800-802.

25. Levine $L:$ Tamoxifen stimulates arachidonic acid release from rat liver cells by an estrogen receptor-independent, nongenomic mechanism. BMC Cancer 2003, 3:24

26. Levine $L$ : Statins stimulate arachidonic acid release and prostaglandin $\mathbf{I}_{\mathbf{2}}$ production in rat liver cells. Lipids Health Dis 2003 , 2:I.

27. Levine L: Proteasome inhibitors: their effects on arachidonic acid release from cells in culture and arachidonic acid metabolism in rat liver cells. BMC Pharmacol 2004, 4:15.

28. Cormier RT, Hong KH, Halberg RB, Hawkins TL, Richardson P, Mulherkar R, Dove WF, Lander ES: Secretory phospholipase Pla2g2a confers resistance to intestinal tumorigenesis. Nat Genet 1997, 17:88-91.

29. MacPhee M, Chepenik KP, Liddell RA, Nelson KK, Siracusa LD, Buchberg AM: The secretory phospholipase $A_{2}$ gene is a candidate for the Mom I locus, a major modifier of ApcMin-induced intestinal neoplasia. Cell 1995, 81:957-966.

30. Thastrup O, Cullen PJ, Drobak BK, Hanley MR, Dawson AP: Thapsigargin, a tumor promoter, discharges intracellular $\mathrm{Ca}{ }^{2+}$ stores by specific inhibition of the endoplasmic reticulum $\mathrm{Ca}^{2+}$-ATPase. Proc Natl Acad Sci U S A 1990, 87:2466-2470.

31. Orrenius S, Zhivotovsky B, Nicotera P: Regulation of cell death: the calcium-apoptosis link. Nat Rev Mol Cell Biol 2003, 4:552-565.

32. Shiff SJ, Rigas $B$ : The role of cyclooxygenase inhibition in the antineoplastic effects of nonsteroidal antiinflammatory drugs (NSAIDs). J Exp Med 1999, 190:445-450.

33. Rigas A, Levine L: Arachidonic acid metabolism by rat liver cells (the C-9 cell line). J Pharmacol Exp Ther 1984, 23 I:230-235.

34. Chan TA, Morin PJ, Vogelstein B, Kinzler KW: Mechanisms underlying nonsteroidal antiinflammatory drug-mediated apoptosis. Proc Natl Acad Sci U S A 1998, 95:68I-686.

35. Hannun YA: Functions of ceramide in coordinating cellular responses to stress. Science 1996, 274: |855-|859.

36. Christensen SB, Andersen A, Kromann H, Treiman M, Tombal B, Denmeade $S$, Isaacs JT: Thapsigargin analogues for targeting programmed death of androgen-independent prostate cancer cells. Bioorg Med Chem 1999, 7:1273-1280.

37. Teh BS, Chen P, Lavin MF, Seow WK, Thong YH: Demonstration of the induction of apoptosis (programmed cell death) by tetrandrine, a novel anti-inflammatory agent. Int J Immunopharmacol 1991, 13:1 I 17-1 I26.

38. Laye JP, Gill JH: Phospholipase $\mathbf{A}_{2}$ expression in tumours: a target for therapeutic intervention? Drug Discov Today 2003, 8:710-716.

39. Diaz BL, Arm JP: Phospholipase A. Prostaglandins Leukot Essent Fatty Acids 2003, 69:87-97.

40. Walter MF, Jacob RF, Day CA, Dahlborg R, Weng Y, Mason RP: Sulfone COX-2 inhibitors increase susceptibility of human LDL and plasma to oxidative modification: comparison to sulfonamide COX-2 inhibitors and NSAIDs. Atherosclerosis 2004 177:235-243.
4I. Levine L: Stimulated release of arachidonic acid from rat liver cells by celecoxib and indomethacin. Prostaglandins Leukot Essent Fatty Acids 200I, 65:31-35.

42. Levine L: Measurement of arachidonic acid metabolites by radioimmunoassay. In Manual of Clinical Laboratory Immunology 3rd edition. Edited by: Rose NR, Friedman H, Fahey JL. Washington DC: American Society for Microbiology; 1986:685-691.
Publish with Bio Med Central and every scientist can read your work free of charge

"BioMed Central will be the most significant development for disseminating the results of biomedical research in our lifetime. "

Sir Paul Nurse, Cancer Research UK

Your research papers will be:

- available free of charge to the entire biomedical community

- peer reviewed and published immediately upon acceptance

- cited in PubMed and archived on PubMed Central

- yours - you keep the copyright
Biomedcentral 